\title{
PReS13-SPK-1575: Science of pain amplification
}

\author{
RF Howard ${ }^{1,2}$ \\ From 20th Pediatric Rheumatology European Society (PReS) Congress \\ Ljubljana, Slovenia. 25-29 September 2013
}

Pain perception is subject to powerful modulatory influences that can increase or reduce subjective responses in the short and long term. Nociceptive circuits can become sensitised causing both innocuous and noxious inputs to be amplified and their intensity and other sensory characteristics to be increased. Both central and peripheral mechanisms of sensitisation are recognised. Nociceptive mechanisms are immature at birth, undergoing both structural and functional change during normal development that can have important consequences for the maintenance, management and prognosis of chronic pain in children.

The neurophysiology of pain in children will be briefly described with special reference to sensitisation in the context of non-inflammatory musculoskeletal pain and pain amplification syndromes. A mechanisms based approach to the medical management of chronic pain in children will be discussed.

\section{Disclosure of interest}

None declared.

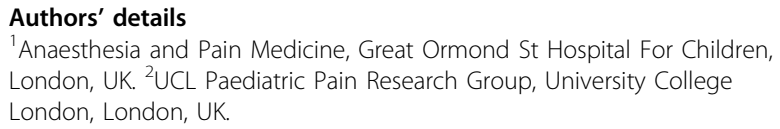

Submit your next manuscript to BioMed Central and take full advantage of:

- Convenient online submission

- Thorough peer review

- No space constraints or color figure charges

- Immediate publication on acceptance

- Inclusion in PubMed, CAS, Scopus and Google Scholar

- Research which is freely available for redistribution

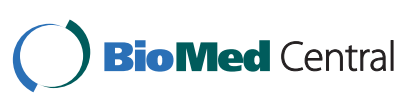

